\title{
One of the Children
}


Men and Masculinity

Michael Kimmel, Editor

1. Still a Man's World: Men Who Do 'Women's Work", by Christine L. Williams

2. One of the Children: Gay Black Men in Harlem, by William G. Hawkeswood, edited by Alex W. Costley

3. The Meanings of Macho: Being a Man in Mexico City, by Matthew Gutmann 


\title{
One of the Children
}

Gay Black Men in Harlem

\author{
William G. Hawkeswood
}

EDITED BY

Alex W. Costley

UNIVERSITY OF CALIFORNIA PRESS

Berkeley / Los Angeles / London 
University of California Press

Berkeley and Los Angeles, California

University of California Press

London, England

Copyright 1996 by The Regents of the University of California

Library of Congress Cataloging-in-Publication Data

Hawkeswood, William G., d. 1992.

One of the children : gay black men in Harlem / William G.

Hawkeswood ; edited by Alex W. Costley.

p. $\mathrm{cm} .-$ (Men and masculinity ; 2 )

Includes bibliographical references and index.

ISBN 0-520-08112-9 (cloth : alk. paper)). -

ISBN 0-520-20212-0 (pbk. : alk. paper)

1. Afro-American gays-New York (N.Y.) 2. Gay

communities-New York (N.Y.) 3. Harlem (New York, N.Y.)Social conditions. 4. AIDS (Disease)-New York (N.Y.)

I. Costley, Alex W. II. Title.

III. Series: Men and masculinity (Berkeley, Calif.) ; 2.

HQ76.2.U52N55 1996

305.38'9664'097471-dc20

94-49565

CIP

Printed in the United States of America

$\begin{array}{lllllllll}1 & 2 & 3 & 4 & 5 & 6 & 7 & 8 & 9\end{array}$

The paper used in this publication meets the minimum requirements of American National Standard for Information Sciences-Permanence of Paper for Printed Library Materials, ANSI Z39.48-1984@ 
To Sasbi 
